\title{
SMALL BUSINESS AND START-UP CAPITAL: GRILLING THE FLORA AND CONFIGURATION OF THE FINANCIAL CAPITAL FOR A VIABLE SMALL BUSINESS
}

\author{
Anifowose, Oluwafemi Dele \\ Ekiti State University, Nigeria, Department of Entrepreneurship, Faculty of Management Sciences \\ Email: sylanfos2004@yahoo.com
}

\section{Onileowo, Teniola Temitope}

Ekiti State University, Nigeria, Department of Entrepreneurship, Faculty of Management Sciences Email: k_tennie1@yahoo.com

\begin{abstract}
The term finance or financing is comprehensively stared as a kernel and a 'key' gizmo that is obligatory for the evolution and functionality of any enterprise. Accessing the appropriate kind of financing in accord to the enterprise's need is more essential for its survival. However, access to finance for small and medium enterprises (SMEs) has always been difficult to owners and also, a serious apprehension especially among researchers. Meanwhile, it is on the note that very many small business sector offer support to Nigerian economy by providing employment opportunity to most citizens who in turn improves standard of living. But, in spite of this importance, most of these small businesses collapse within the first five years of operation yet the agencies established by Nigerian Government to offer support to this sector are confronted with difficulties in accessing the finance from financial institutes. Keeping in view the importance of SMEs, this paper grilling the flora and configuration of the financial capital for viable small business is to widen the understanding on the existing financing opportunities available to SMEs and entrepreneurs.
\end{abstract}

KEYWORDS: Small and Medium Enterprises (SMEs), finance, start-up capital, market.

\section{INTRODUCTION}

The idea of establishing small and medium-sized enterprises (SMEs) is generally viewed to contribute significantly to economic growth, employment, innovation and social stability across the globe. They are also regarded as a major driver of innovation for sustainable development and economic growth that has gathered substantial attention during the last several decades. In order to speed up the sustainability evolution, further attention should be given to the financial needs of SMEs. This is because, availability of financial capital is very essential for the survival of any business enterprise and is also considered as one economic resource measured in terms of cash utilized by entrepreneurs and businesses to shop for what they need to make their products or to offer their services to the sector of the economy upon which their operation is based, i.e. retail, corporate, investment banking, etc.

However, access to financial capital to purchase fixed and current assets is crucial to sustaining a firm's competitive advantage. Empirical studies such as Wiklund and Shepherd (2004), Zhou and Chen (2008) ascertain that Small and medium enterprises need financial capital to acquire physical resources to enable them to take advantage of business opportunities. Likewise, Bolingtoft et al. (2003) state that, to establish and sustain an SME, the entrepreneur needs to have access to various types of resources such as (i) financial capital; (ii) human capital; and (iii) material capital; with each performing different, but similar important roles during the process of founding a new enterprise. 
Strong financial health and access to a wide capital base are paramount not only for survival across the fluctuating macroeconomic business cycle, but also for financing strategic business transitions, as well as succession and entrepreneurial rebirth. Garcial-Teruel and Martinez-Solano (2007) point out that non- accessibility to working capital is a major constraint to the sustainability and growth of new SMEs.

Consequently, starting up small businesses are often accompany with numerous challenges ranging from funding, markets and skills in developing economies which restraint their growth and survival, as supported by Dugguh (2015), that small businesses in Nigeria are confronted with numerous challenges that resulted in their failure. Meanwhile, financing small business remains one of the foremost important factors determining the survival and growth of small businesses notably in developing economies. Suffice it to stress that accessing capital for new entrepreneurial pursuit has not always been an easy task in Nigeria though several Nigerian entrepreneurs have recorded successes within the area of business however the evident is that more entrepreneurial dreams are aborted at conception because of financing constraints even though Small businesses have been widely acknowledged as the spring board for sustainable economic development.

Since the 1970's in Nigeria, there has been an accrued interest within the promotion of small businesses due to the failure of government and mega organizations to employ the nation's swarming populace. This has reinforced the individuals' self-supporting and self-dependent perception to the recognition that dynamic and growing small businesses will contribute considerably to a large range of national developmental objectives. Hence, strengthening the controversy the way to improve poor economic condition could also be to extend the productivity of those engaged in small scale production (Aftab \& Rahim 1989).

The small business community in a country like Nigeria has assumed worldwide recognition and relevance founded on its potentials for creating self-employment, balanced development of regional utilization of obtainable localized resources. They play active role in generating and providing employment opportunities at lower cost. Entrepreneurs who engage in small business in developing countries typically mention lack of capital as a significant constraint to entrepreneurial development, a perception usually denoted as "capital illusion".

This lack of access is usually related to financial policies and bank practice that make it difficult for banks to bear the high costs and risks involved in providing loans to small business. Considering their nature, small and medium scale business need future capital for investment, as a results of their long gestation periods. According to Lampadarios (2016), the enterprise success factors of small businesses comprise age and size of the company, business network, consumer relations management, financial resources, internationalization, human capital, market and product development, marketing, and strategic planning, thus financing small business has become one of the key challenges that contravene small business success in Nigeria. The capital to invest is significant to the growth of small businesses sustenance and survival.

However, financing small business has become one of the main challenges that is working against small business success in Nigeria. The capital to invest is significant to the growth of small businesses sustenance and survival. Gbandi and Amissah (2014) opined that the incapacity of small businesses to access long-term financing contribute immensely to its failure in Nigeria. In the same way, Akinola and Iordoo (2013) informed that, inadequate funding of small businesses remain their 
barrier with Nigerian capital markets. Inadequate financial institutions funding contributed to the massive failure of small businesses in Nigeria because they tried to avert risk associated with small businesses financing. Likewise, small business owners and managers avoid financial institutions loan due to inappropriate loan procedures and high interest rates which made it difficult for them to make a meaningful profit. The challenge is for small business owners and managers to seek out initial capital and additional capital to grow their business and sustain operations within the first five years.

SMEs in Nigeria have restricted access to short-term credit from banks as a result of the absence of collateral security, poor record keeping, poor creditworthiness, and inadequate project proposals (Abe, 2015). The Nigerian banking regulations only require banks to use $10 \%$ of their pretax income to fund SMEs (Tende, 2014). The general business problem is that the shortage of bank credit negatively affects some SME business leaders thus, has serious consequence on the performance of that SMEs' growth and development in Nigeria (Abe, 2015; Ugoani \& Dike, 2013). The specific SMEs problem today is of sources of funds necessary for the growth and development of their businesses (Gbandi \& Amissah, 2014).

\section{The Nature and Structure of Business Environment}

Business is referred to as an economic activity of generating revenue through buying and selling, manufacturing and rendering auxiliary services to trade. The term "Environment" refers to anything which surrounds a particular organization. Thus, Business Environment suggest that surroundings (including human beings) in which business operates in a certain environment where each business entity has its own environment. The Business environment is regarded as the combination of internal and external factors that influence a company's operational location, as well as employees, customers, management, supply and demand and business rules and regulations.

The Business environment is an environment that is made up of the subsequent factors such as: customers and suppliers; its competition, and owners; advances in technology; laws and government activities; and market, social and economic trends. Another scholar has defined business environment as 'the forces, factors and establishments through which the businessman has to interact with in order to accomplish its goals and objectives'. Thus, Business Environment is perceived as the summation of all external and internal factors that influence a business altogether. The Internal business environment consists of those factors that contribute to the business success/failures or influence decision making for the business. They include; the value system, vision, mission and objectives, Management structure and nature, internal power relationship, human resources, company's image and brand equity. While the External business environment comprises of a Micro environment and a Macro environment.

The Micro environment comprises of the actors within the company's immediate environment that affects the performance of the corporation. These include the suppliers, marketing intermediaries, competitors, customers and therefore the publics." The macro environment comprises larger societal forces that have an effect on all the actors in the company's micro environment mainly, the demographic, economic, natural, technical, political and cultural forces." It's quite obvious that the micro environmental factors are more intimately connected with the company than the macro factors. The micro forces needn't essentially have an effect on all the companies in a specific trade in the same way. Some of the micro factors could also be specific to a firm. For example, a firm that depends on a supplier could have a supplier environment that is completely different from that of a firm whose offer supply is different. 
According to Miller and Redding, 'In any field of study or activity, as well as financial accounting, there are variety of reasons for developing a conceptual framework, which represents a collection of broad rules, guidelines, accepted truths, and alternative basic ideas regarding the field. Business usually in spite of its size, nature/structure or environment of it operation, is confronted with very many challenges or the other in their cause of operation, Adebusuyi (1997) perceived that, a number of these challenges function as tool/ladder to their success by way of encouraging entrepreneurs to learn from their mistakes, whereas some remain as threats to their every operations.

Meanwhile, small and medium enterprises (SMEs) are considered the backbone of economic growth in all countries. They play an important role in Nigerian's economic growth, as they constitute $97.2 \%$ of the companies in Nigeria. They conjointly contribute to national development by absolutely influencing the distribution of revenue in both functional and nominal terms. Investing in small scale businesses has a great potential for growth, as importance emphasized by Rogers states that: they enhance capacity building as they serve as entrepreneurial training avenues; they produce a lot of employment opportunities per unit of investment attributed to their labour intensive operations; they accomplish a considerable relative high value added operations as a result of being propelled by basic economic activities that rely totally on locally sourced raw materials; they offer feeder industry services as they function as main suppliers of intermediate products and components to large-scale industries likewise as major agents for the distribution of final products of such industries; they offer opportunities for the growth of local skills and technology acquisition through adaptation. Despite the catalytic role of SMEs in the economic emancipation of countries, there are major operational challenges and problems affecting SMEs in Nigeria, this includes:

\section{Financial Capital Problem}

The issue of raising set up capital to start a business enterprise appeared to be a major problem that impedes the growth and development of small business operations in Nigeria. Nearly $80 \%$ of Small and medium enterprises are restrained as a result of poor financing and other associated problems. The problem of financing SMEs start from the accessibility of funds. There are certain factors recognized as responsible in preventing accessibility of funds that are severe conditions set by financial institutions, lack of adequate collateral and credit information and cost of accessing funds. Harper considers that the capital shortage difficulty related to the small firm sector is partly one, which stems for the uneconomic deployment of available resources by the owner-managers. An opinion expressed by Ihyembe who claimed to have witnessed some businessmen obtain loan for development projects only to take new wives, get chieftaincy titles or purchase houses abroad. Bruch and Hiemenz in a study of SMEs in Asia observed that financing working capital needs was the most frequently mentioned problem. According to Binks and Ennew [19] expressed the opinion that the funding problem of SMEs is primarily as a result of banks behavior and imperfection of the capital markets.

\section{Business Management Problem:}

Lack of trained manpower and managerial skills do also constitute a major challenge to the survival of SMEs in Nigeria. West and Wood, aforementioned that "...90\% of all business failures result from lack of experience and competence. Rogers affirmed that incompetence in overall business management and poor record keeping is a serious problem related to most SMEs. These include; technical problems/competence and lack of essential and required skillfulness in production, 
purchasing, maintenance, marketing and finances have always led to funds misappropriation, wrong and costly decision making.

Management applies to all kinds of organizations and to managers in all levels of organization. Principles of management are currently used not just for managing business however in all walks of life viz., government, military, social and academic institutions. Basically, management is same process applicable in all forms of organization. However it could vary generally in its complexity with size and level of organization. Management is the life giving component of any organization. Henry Fayol opined that. "Management is regarded as way of affairs of business, moving towards achieving its objective through a continuous method of development and maximization of resources. Hence, Management involves planning, organizing, staffing, directing, and controlling which are taken to achieve organizational goal.

\section{Limited Basic Business Infrastructure}

The problem of basic business infrastructure is another factor that contributes to the poor performance of small business operations in Nigeria. Government has not done enough to create a conducive environment for the striving of SMEs, the problem associated with infrastructures are numerous which ranges from shortage of water supply, insufficient transport systems, lack of electricity to improper solid waste management. Nigeria is underdeveloped in terms of physical and social infrastructures as this create a binding constraint to SMEs growth. Most business in Nigeria heavily relies on the inefficiently provided state infrastructures and cannot afford the cost of developing alternatives.

\section{Location /Economic Factors}

It is observed that most market stores are dominated by absentee landlords who charge excessive rates. The possession of market stores by politicians is crowding and as a result, some small-scale operators are forced out of the market. The high rents being charged by store owners on smart locations have forced genuine small-scale operators into the streets or at best into accessible places. Similarly, domestic economic problems of deregulation and removal of protection couple with the global financial crisis have been detrimental to SMEs performance.

\section{Nigeria Tax System}

This has become a serious problem particularly given the role of tax consultants and agents employed by local governments. They are usually rudimentary in their operation, excessive in their assessment and damaging in their relationship. They tax everything in their effort to get revenue while not considering the gross effect on family incomes and employment.

\section{Government Regulatory System}

The uncertainty of government policies have caused some SMEs to collapse as a result of the current high mortality rate of SMEs in Nigeria which is awful to contemplate and also constitute danger to the entire economic system. It embodies serious financial pressure on the nation's economy as well as a waste of valuable resources. The business owner should always consider challenging situations and be ready to satisfy them with pre-planned approaches. The survival of SMEs is simply achievable through a systematic analysis of the challenges they are facing and mapping out applicable ways of overcoming them, through appropriate understanding of the business and the environment. For any business to survive in unfriendly environments it ought to adopt a policy that utilizes its strengths to exploit opportunities while avoiding its weaknesses. Thus, any entrepreneur 
who wishes to succeed must identify business opportunities, be determined, be creative, profound, and enterprising, risk taking, courageous and sensitive to changes in the business environment.

\section{SOURCES OF FUNDING AVAILABLE TO SMALL BUSINESS}

Financing has been acknowledged in various small business surveys as one of the most key factors that determine the survival and growth of small enterprises (Moses, 2010). Mambula (2002) acknowledging this affirms that small businesses in Nigeria suffer from the dearth of funding as topmost amidst other different constraints. The access to finance allows small business to undertake productive investment which gives it the opportunity to expand their business and to procure the latest technologies, thus ensuring their competitiveness and that of the entire nation. The following includes the sources of funding available to SME's

\section{Personal Saving}

When SME owners face lack of capital, the primary and foremost possibility is to source finance on his own from available sources and to seek assistance from his friends and family. This kind of funding is considered as source of trust capital. In Nigeria $73 \%$ of SMEs raised their own funds from financing personal savings; borrowed funds from friends and family whereas, only about $2 \%$ opted financial institutions for financing (Terungwa, 2011). Owing to high interest rate and complex procedure, SMEs in Pakistan ranks $3^{\text {rd }}$ at bank credit followed by funding from NGOs and family and friends (Nenova et al., 2009).

\section{Borrowing from Friends and Family}

In practice, raising finance from friends and family is another good alternative as the investors only purpose is not financial and is prepared to accept the lower or no interest on their investments. Funding from friends and family has few shortcomings; risk remains among the social circle of owner and might have an effect on the relationship in such a negative way (Lee and Parson, 2016); another disadvantage is that, such kind of financing is limited.

\section{Trade Credit}

Trade credit can be regarded as an alternative method of financing business needs. It arises when a company purchases good and services on deferred payment (Huyghebaert, 2006). It's a short-term credit and payment becomes due within thirty to sixty days; if payment is not made within the specified time period, interest rates are charged and become a source of financing. Trade financing is general; other than traditional bank lending, it's the following most external significant approach of SME financing in almost all developed and developing countries (Demirgüç-Kunt and Maksimovic, 2002). Trade credit is a spontaneous kind of financing for SMEs, as it occurs directly from ordinary business transactions.

Though, if payments are not made within the required credit window, trade credit can become an expensive way of financing. In addition, cost of credit is generally assigned into the cost of goods sold on credit, which indirectly makes trade credit as an expensive financing approach (Wilson and Summers, 2002). The period of trade credit is restricted, especially when such SME is more exposed to risk, suppliers may be unwilling to extend the credit period further. Meanwhile, trade credit has few shortcomings but it is still regarded as essential source of financing for start-up SMEs (Berger and Udell, 2006). 


\section{Leasing}

Leasing is regarded as an asset based type of financing in business, which allow SMEs to obtain the short -term and medium-term financing. It can also be referred as source of financing for purchasing capital equipment, where two parties decide to sign a contract where one party known as the (lessor) provides an asset to another party (lessee) for using that asset for limited/fixed period of time against the specified regular payments. At the end of contract, the lessee is allowed to buy that equipment. (Amiri, 1998 and Fletcher et. al., 2005).

It is on the note that Leasing is considered as one of the vital financing tool for SMEs which allow them almost same to the investment period of leased assets. It is different from traditional loan as there is no cash given to client by a finance company, but an asset. Government support for this financing tool may assist to minimize the market weaknesses and to expand the SMEs access to finance. Leasing is quite effective for small businesses when they face difficulty to access the traditional bank credit due to having limited credit track and lack of collateral but leasing enables them to use capital equipment. (Gollardo, 1997 and Berger and Udell, 2006). Leasing is mostly used by fast-growing SMEs especially in European countries (Kraemer and Lang, 2012).

In the contemporary financial and monitory situation, leasing companies have also limited access to (re-financing). Mostly leasing companies are owned by banks; in Europe 90\% leasing companies are bank-owned and other than bank-owned leasing companies, sovereign and captive leasing companies also heavily depend on banks funding to carry out their operations (Mignerey, 2012). SMEs considered leasing as an essential part of their financing solution however the supply side has been affected as a result of financial and economic crisis. The recent financial crisis not only affected the banking industry but also the leasing sector by the deteriorating of re financing conditions and several banks have reduced or completely abandoned the refinancing of leasing companies, because of lack of bank's own resources, strict monitoring requirements and management pressure to center effort on low equity base or scarce of specialization that often leads to relatively low residual value of leased assets in their balance sheets (Arzeni et al. 2015).

\section{Equity Financing}

Equity financing is thought to be a source of financing that corporation raise capital by trading the stocks to investors, and take over the ownership rights in the company. In line with Ou \& Haynes, (2006, p. 156) said that "equity capital is that capital licensed within the firm without a particular date of refund, where the provider of the fund is proficiently funding the enterprise" Meanwhile, equity finance could be considered as one of the best method suitable for funding small business enterprises especially those that have high portfolio risk and return, seeking long-term corporate investment for expansion, enduring innovation and worth creation. Equity financing is most popular over debt finance, as debt finance is expensive, not appropriate for short-term and troublesome to access.

Equity financing is benefits to the SME by providing long-term financing with least cash outflow in terms of interest and assist the new businesses to increase their credibility by demonstrating that they have seasoned financial consultants (Ou and Haynes, 2006). These firms are generally referred as high risk. Troubles confronting SMEs looking for public equity financing are not only constrained to cost (confirmation charges, guides and broker commissions), formalities and reporting necessities. Social variables and administration rehearses additionally constitute challenges for SMEs. The uncertainty to experience the offering procedure, apprehension of being vulnerable to share price 
instability, dislike for sharing sensitive information and life after an IPO is imperative purposes behind SME hesitance to join value capital markets (Nassr and Wehinger, 2016).

Reid (1996), argued that some SMEs many do not choose equity as source of financing to avoid any unwanted changes in the ownership of their businesses.

\section{SMALL BUSINESS FINANCE: FACTORS THAT DETERMINE THE ESTABLISHMENT OF SMALL BUSINESS}

\section{Access to Finance}

In spite of their dynamic role in ensuring and building a competitive private sector as well as contributing significantly to employment growth, SMEs are facing more challenges in accessing financial resources. SMEs are particularly constrained by gaps in the financial system, such as high interests' rate, high collateral requirements, and lack of experience with financial intermediaries. The Algerian banking system is large but is dominated by state-owned banks; moreover, Algerian banks have some of the highest rates of credit concentration in the world. SME financing in Algeria is dominated by banks, with capital markets and non-bank financial institutions (NBFIs) being insignificant financing sources. SME growth potential is also restricted when entrepreneurs are denied credit, despite having adequate cash flow or purchase orders, due to collateral requirements or to high interest rate. A high proportion of loans for both small and large firms among the selected region in the world require collateral; however, Algerian banks tend to impose high collateral values as a ratio of the SME's loan amount. For this reason, SMEs rely on their personal savings and informal financing to finance different investments and operations. Access to financing remains highly unfavorable for SMEs in Algeria. The high interest rates and high collateral requirements among banks make it very difficult for SMEs to receive credit.

\section{Managerial Skills}

Management skills are the critical success factors of all businesses which involve the ability of organizing, owning, managing and assuming the risks of business, and small business is no exception. The absence of managerial skills places major challenges on the performance and development of SMEs. The scarcity of management talent in Algeria has a huge impact on SMEs and can hinder the progress of their development. Moreover, the lack of support services or the irrelatively higher unit cost can hinder SMEs' efforts to improve their management, because new and inexperienced entrepreneurs may not have the necessary skills and managerial capability to be able to fully exploit new opportunities and markets.

\section{Taxation Policy}

The concept of tax plays significant role in the growth of Small and Medium Enterprises (SMEs). In the low-income country like Kenya, role of SMEs is critical in advancing the socio-economic development agenda of the country forward. Thus, alignment of the tax-system to the environment specific to SME growth needs can be considered an important agenda for the policy makers. In view of this, the study aimed to explore the managers/executive officers ${ }^{\text {ee }}$ perception of tax-system effectiveness in promoting SMEs growth in the Country. Taxation policy has an effect on and business costs directly, for example, an increase incorporation tax (on business profits) has the same influence as a rise in costs. Enterprises can pass some of this tax on to consumers in higher prices, but it will also have an effect on the bottom line. Other business taxes include VAT (value added tax). VAT is actually passed down the line to the end user but the administration of the VAT system is a cost for business. Some of the SMEs do not make high profits hence with high taxes in places; 
they are unable to sustain themselves leading to their closure. Assessing the impact of tax systems on SMEs is not simply a matter of looking at tax rates. However, Tax systems play a significant role in encouraging growth, investment and innovation and enabling international trade and movement. For SMEs key considerations are to minimize administrative burden while ensuring compliance, together with considering the drivers and impacts of operating in the informal economy.

\section{Physical Infrastructure}

Physical infrastructure is regarded as the totality of basic physical facilities upon which all other economic activities in the system significantly depend (Ukpong and Iniodu, 1991). According to Hirschman (1958), infrastructures are those services without which primary, secondary and tertiary production activities cannot function. Therefore, these infrastructures can be extended to include education, public health to transportation, communication, power and water supply. Infrastructure therefore, can be seen as both a final good providing services directly to consumers and intermediate input that enter into the production function of other sectors and raises the productivity of the factors employed.

Infrastructure therefore, can serve as an externality variable that can facilitate the production function of private sector, thereby improving the efficiency of the factors of production and growth. Kessides (1993) Discusses that: Infrastructure gives a boost to economic growth both through supply and demand channels by reducing cost of production, contributing to the application of modern technology, improving the economic returns of labour (thereby reducing employees' time in nonproductive activities or improving health), Infrastructure contributes to improving the quality of life by providing amenities, supplying consumption goods (transport and communication services) and promoting Macroeconomic stability.

Infrastructure contributes to economic development through the promotion of private sector development by increasing access to the factors of production, goods and market (Tsauni, 2005). Thus, an efficient transport network boosts the growth potential of a country and is liable system of energy generation and distribution brings modern technologies and processes to SMEs. In addition, infrastructure could enable SMEs to work cooperatively and achieve economies of scale, as well as ensure price and non-price competitiveness. High transport costs linked with movement of goods from the rural to urban regions in particular is becoming more vulnerable as fuel price keep increasing.

Furthermore, a dependable system of energy at an affordable price is essential to all economic activity and failure to provide accessible power sources is a constraint to production efficiency and competitiveness. Obadan (2004) submits that infrastructural deficiencies are the frequent complaints by all businesses in so many countries, local and foreign owned firms, alike. It is noteworthy that power failure, transport costs and other infrastructural problems among SMEs poses the greatest difficulties to continued business activity. Building physical and social infrastructures have become a cornerstone for business development.

However, funding small scale businesses has a great tendency for growth if not hindered by some identified challenges like poor managerial knowledge, in adequate capital and lack of Government support. The ease for establishing a small scale business has aided the spread of small scale businesses in recent time. SMEDAN (2012), opined that small scale businesses have been hindered by various constraints, including illiteracy, inadequate financing, unfavorable government policy, 
poor management practices and lack of managerial skills. According to Mba and Emeti (2014) after conducting a study on Issues, Challenges and Prospects of Small and Medium Scale Enterprises (SMEs) in Port-Harcourt City, Nigeria. The research found out that lack of fund and poor managerial skills were the key challenges and suggested that stakeholders should take it as their responsibilities in handling some of the challenges. Likewise, Anigbogu, et al (2014) also found out a study on Roles of Small and Medium Scale Enterprises in Community Development: Evidence from Anambra South Senatorial Zone, Anambra State, Nigeria. Even though various studies recognized some of these challenges that affect the operation of small scale business. Small-scale businesses are perceived as instrument of growth and development for any sustainable economy (Oduyoye, Adebola, and Binuyo, 2013), because of their impacts on employment generation and technological advancement in the society, hence inadequate capital may affect it performance and activities. The ability to generate finance each internally is incredibly vital for the flourishing operation of each business set-up, where such capital is not adequately available, in turn will affect the smooth operation of the business. Lamu, (2014) declared that, adequate capital is very essential not only to new found businesses but also to an existing business. For a replacement business it's rarely that the founders can generate the proper size of finance from their own non- public resources to satisfy all the initial expenses. Therefore, the urge is so imperative for the founder to appear each within among themselves and outside their immediate business environment for extra finance to fund the operation of the business enterprise.

The interrogation now is, how do small scale business owners source for capital? Capital is very significant to the success of every business, and where such is inadequate will affect the smooth operation of the business. There are various sources of finance available for small scale businesses. Akingunola (2011) further stated that, the major sources of financing small and medium scale businesses can be categorized as debt and equity. Meanwhile in their own part, Adebusuyi, (1997; Mbasua, (2014), categorized various sources of finance for small scale businesses into two categories as; Internal source of finance and the External sources of finance. The Internal Sources of finance are those type of funds that are generated within the business. These sources of finance are very affordable and easy to access compared to external sources; these include; personal saving, family and friend financial support and re-investing revenue. Whereas the external sources of funds for small and medium scale enterprises are; trade credit, bank loan, hire purchase, lease of equipment and debenture. According to Mba and Emeti, (2014) opined that, external sources of funds for SSBs are risky and costly in nature. Likewise (Owualah, 1999; Aminu, 2012) discoursed that, there are seven main sources of finance available to SSBs, these are; Personal resources, Family and friends, Partners or business associates, Informal financial markets comprising, individuals and group, including pool fund groups and cooperative societies, Banks (commercial and merchant), and community banks, Specialized funding facilities e.g. NERFUND, the World Bank Loan Scheme for SMEs managed by the Central bank of Nigeria (CBN) and the African Development Bank (ADB) loan scheme for export stimulation in the SME region, SMIEIS and Specialized financial institutions such as the Nigerian Bank for commerce and Industry (NBCI), Nigerian Industrial Development Bank (NIDB) and the Nigerian Agricultural and co-operative Bank (NACB).

\section{CONCLUSION AND RECOMMENDATION}

The paper discussed issues, challenges and sources for opening capital for small business enterprises in Nigeria. It is important to note that finance is an inevitable tool for SMEs growth and development of any state or country. However, financing SMEs within the state is confronted with some 
challenges of where to source for capital to open new or expand an existing venture; the problem has extremely distorted the growth of entrepreneurship within the state. It presumed that government intervention through the availability of financial assistance, social infrastructures and favorable taxation policies can go a long way in addressing the foremost challenges and finance of SMEs. It was observed that several factors contribute to the poor performance of SMEs such as: Poor financing which constitutes a serious challenge within the performance of SMEs, poor social infrastructures which is one of the major factors affecting the performance of SMEs, lack of quality managerial skills is another major challenges that impede the performance of SMEs, and multiple taxation constitutes a severe challenge within the performance of SMEs. Thus, the existence of Micro finance institution within the state was to be an instrument of relief in reducing the problem of finance that SMEs encounter, nonetheless quite variety of entrepreneurs doesn't seem to be knowledgeable concerning it existence. To ensure effective SMEs finance for entrepreneurial development within the state, the state government interventions funds programmes seek to stimulate the economy as well as to reduce poverty level. Small business owners within the state ought to be sensitized on the operations of Micro Finance institutions. This can be achieved through awareness creation on the aim and activities of Micro Finance Institutions and wherever these institutions can be contacted.

\section{REFERENCES}

Abe, M. (2015). Financing small and medium enterprises in Asia and the Pacific. Journal of Entrepreneurship and Public Policy, 4, 2-32. doi:10.1108/JEPP-07-2012-0036

Adebusuyi, B. S. (1997). Performance Evaluation of Small-medium Enterprises (SMEs) in Nigeria. Bullion, 21 No. 4 Central Bank of Nigeria.

Aftab, K. \& Rahim, E. (1989). Barriers to the growth of informal sector firm: A case study. Journal of Development Studies, 25(4), 60-76.

Akingunola, R. O (2011). Small and Medium Scale Enterprises and Economic Growth in Nigeria: An Assessment of Financing Options, Pakistan Journal of Business and Review. Volume 2 (1)

Akinola, A. O., \& Iordoo, D. A. (2013). The effect of Nigerian capital market on the micro, Small and medium scale enterprises (MSMEs) in Nigeria. Journal of Finance and Accounting, 4(7), 1-14. Retrieved from http://www.iiste.org

Aminu. A. A (2012), " Entrepreneurship Theory and Practice", published by Intellectual Property and Technology Transfer Office (IPTTO0 University of Maiduguri, Nigeria

Amiri, Mohamed (1998), "Challenges and opportunities in reaching SME through Leasing, Egypt Experience ee", available at http://archives.entreprendre mediterranee.com/documents/colloque-Acim-tunis-2006/Session3/Amiri- Egypteanglais.pdf

Anigbogu, T. U.; Onwuteaka, C. I.; Edoko, T.D; and Okoli, M. I. (2014). Roles of Small and Medium Scale Enterprises in Community Development: Evidence from Anambra South Senatorial Zone, Anambra State, Nigeria. International Journal of Academic Research in Business and Social Sciences Vol. 4, No. 8, PP 302-315

Arzeni, S., Cusmano, L., \&Robano, V. (2015). Access to Finance for SMEs and Entrepreneurs: Trends and Policies in OECD Countries. In Public Private Partnerships for Infrastructure and Business Development(pp. 189-220). Palgrave Macmillan US 
Asma B.B, Diabate A., Othman A. (2015) Establishing the Factors Affecting the Growth of Small and Medium-sized Enterprises in Algeria: American International Journal of Social Science Vol. 4, No. 2; April 2015

Berger Allen, N., \& Udell, G. F. (2006). nA More Complete Conceptual Framework for SME Finance, Journal of Banking \& Finance, 30.

Bolingtoft A, Ulhoi JP, Madsen AH, Neergaard H 2003.Effect of financial factors on the performance of new venture companies in high tech and knowledge-intensive industries: An empirical study in Denmark. International J of Management, 20(1): 535-547.

Carey, D., \& Flynn, A. (2005). Is bank finance the Achilles' heel of Irish SMEs? Journal of European Industrial Training, 29(9), 712-729.

Charantimath, P. M. (2012), Entrepreneurship Development \& Small Business Enterprises, $7^{\text {th }}$ Ed. India: Swan Press

Demirgüç-Kunt, A., \&Maksimovic, V. (2002). Funding growth in bank-based and market-based financial systems: evidence from firm-level data. Journal of Financial Economics, 65(3), 337- 363.

Dugguh, S. I. (2013). Entrepreneurship and small business: Strategic approach to alleviating poverty and corruption. GSTF International Journal on Business Review, 3(1), 5766.doi:10.5176/2010-4804_3.1.287

Dugguh, S. I. (2015). Critical issues in managing small and medium enterprises: The Nigeria experience. The International Journal of Business \& Management, 39(9), 52-59. Retrieved from http://search.proquest.com/openview

Elitzur, R., \&Gavious, A. (2003). Contracting, signaling, and moral hazard: a model of entrepreneurs, 'angels,' and venture capitalists. Journal of Business Venturing, 18(6), 709725

Gallardo, J. (1997). Leasing to support small businesses and micro enterprises (No. 1857). The World Bank

Garcial-Teruel PJ, Martinez-Solano P 2007. Effects of working capital management on SME profitability. International J of Managerial Finance, 3(2): 164-177.

Gbandi, E, C.,\& Amissah, G. (2014). Financial options for small and medium enterprises (SMEs) in Nigeria. European Scientific Journal, 10(1), 327-340. Retrieved from http://www.eujournal.org

Hirschman, A. (1958). Strategies of Economic Development. New Haven CT: Yale University Press.

Howe, J. (2008). Crowd sourcing: How the power of the crowd is driving the future of business Random House.

Huyghebaert, N. (2006). On the Determinants and Dynamics of Trade Credit Use: Empirical Evidence from Business Start-ups. Journal of Business Finance \& Accounting, 33(1-2), 305328.

Ivanovic, S., Baresa, S., \&Sinisa, B. (2011). Factoring: Alternative model of financing. UTMS Journal of Economics, 2(2), 189- 206.

Keasey, K., \& McGuinness, P. (1990). Small new firms and the return to alternative sources of finance. Small Business Economics,2(3), 213-222.

Kessides, H. (1993). Infrastructure and Economic Growth. Quoted In:

The 2005 Annual Report of the Ministry of Economic Development. New Zealand

Kirchhoff, B., Newbert, S., Hasan, I. and Armington, C. (2007) 'The influence of university R\&D expenditures on new business formations and employment growth', Entrepreneurship, Theory and Practice, Vol. 31, pp.543-560. 
Kirchoff, B. A. and S. L. Newbert (2007). The influence of university R \& D expenditures on new business formations and employment growth. Entrepreneurship Theory and Practice, 31(4): 1042-2587

Kleemann, F., Voß,G. G., \&Rieder, K. (2008). Un(der) paid innovators: The commercial utilization of consumer work through crowd sourcing. Science, technology \& innovation studies,4(1), PP-5

Lambert, T., \& Schwienbacher, A.(2010). An empirical analysis of crowd funding. Social Science Research Network, 1578175, 1-23.

Lampadarios, E. (2016). Critical success factors for SMEs: An empirical study in the UK chemical distribution industry. International Journal of Business and Management, 11(7), 67- 82. doi:10.5539/ijbm.v11n7p67

Lee, S., \& Persson, P. (2016). Financing from family and friends. The Review of Financial Studies, 29(9), 2341-2386.

Mambula, C. (2002). Perception of SME Growth Constraints in Nigeria. Journal of Small Business Management, 40(1), 58- 65.

Mason, C. M., \& Harrison, R. T. (2008). Measuring business angel investment activity in the United Kingdom: a review of potential data sources.Venture Capital,10(4), 309-330.

Mba, O. A and Emeti, C. I. (2014). Issues, Challenges and Prospects of Small and Medium Scale Enterprises (SMEs) in Port-Harcourt City, Nigeria. European Journal of Sustainable Development, Vol 3(1)

Metzler T. (2011), Venture financing by crowdfunding, GRIN Verlag, Norderstedt, Germany.

Mignerey, J.-M. (2012). Banking Regulation. A "EUR 50 billion leasing crunch" for SMEs in Europe. Leaseurope inside, no. 16, 13 April 2012. Available at: http://www.leaseurope.org/uploads/Banking\% 20Regulation\%20Article.pdf

Mondal, D., \&Shrivastava, A. (2016). Angel Funds: The New Type of Alternative Investment Fund in India.IUP Law Review,6(4)

Mbasua, A.Y. (2014). Business for Beginners, Nigeria: Digital Computers.

Mason, C M and Harrison, R T (2008) Measuring business angel investment activity in the United Kingdom: a review of potential data sources, Venture Capital: an international journal of entrepreneurial finance, 10, 309-330

Nassr, I. K., \&Wehinger, G. (2016). Opportunities and limitations of public equity markets for SMEs.OECD Journal: Financial Market Trends,2015(1), 49-84.

Nenova,T., ThioroNiang, C., \& Ahmad, A. (2009). Bringing Finance to Pakistan's Poor: Access to Finance for Small Enterprises and the Underserved.

Obadan, M. I. (2004c), “Globalization: Elements, Opportunities, Challenges and Risks". A Paper Presented at the Eleventh DPRS Directors Conference, Organised by NCEMA, in Ibadan, $21-25$ June.

Oduyoye, O. O., Adebola, S. A. \& Binuyo, A. O. (2013). Empirical study of infrastructure support and small business growth in Ogun State Nigeria. Journal of Research and Development, 1(1), 14-22

OECD. Publishing. (2010).OECD Studies on SMEs and Entrepreneurship High-Growth Enterprises: What Governments Can Doto Make a Difference. Organisation for Economic Co-operation and Development.

Ou, C., \& Haynes, G. W. (2006). Acquisition of additional equity capital by small firmsfindings from the national survey of small business finances. Small Business Economics, 27(2), 157-168. 
Owualah, S.I. (1999). Entrepreneurship in Small Business Firm: G-MAG Investments Ltd., Ikeja- Lagos. International Journal of Business Management, Vol.6 N0. 4, PP 178. Standard Research Journal of Business Management, Vol.1(2), pp.60-71.

SMEDAN (2012), Survey Report on Micro, Small and Medium Enterprises (MSMEs) in Nigeria. 2010 National

Sohl, J. (2012). The changing nature of the angel market. The handbook of research on venture capital,2, 17-41.

Tende,S. B.A. (2014). Government initiatives toward entrepreneurship development in Nigeria. Global Journal of Business Research, 8, 109-120. Retrieved from http://papers.ssrn.com/sol3/JELJOUR_Results.cfm?...journalBrowser\&journal_id

Terungwa, A., 2011. An empirical evaluation of small and medium enterprises equity investment scheme in Nigeria. Journal of Accounting and taxation,3(3), pp.79-90.

Tsauni, A.M. (2005). 'Infrastructure and Business Performance in Nigeria: Evidence from manufacturing Sector (1985-2004). Conference Paper presented at Department of Business Administration Annual Conference. Bayero University, Kano

Udabah, S.I. (2000)'Productivity and Economic Growth. Department Seminar Paper, Department of Economics, Enugu State University of Science and technology, Enugu

Ukong, I. and Iniodu, P.U. (1991). 'Infrastructure policies and Their Impact on the Development of the Nigerian Economy' In: The Nigerian Economy at Cross Roads: policies and Effectiveness by Ndebbio, L.E. and Ekpo, A.H. (Eds) University of Calabar Press. Calabar.

Vasilescu, L. G. (2010). Factoring-financing alternative for SMEs. In 5th Annual MIDES International Conference, Kavala (pp. 13-23).

Vera, D., \&Onji, K. (2010). Changes in the banking system and small business lending. Small Business Economics,34(3), 293-308. Waseem Ahmed Abbasi, Zongrun Wang\&Danish Ahmed Abbasi 47

Wiklund J, Shepherd D 2005. Entrepreneurial orientation and small business performance: A configurational approach. J of Business Venturing, 20: 71-91.

Wilson, N., \& Summers, B. (2002). Trade credit terms offered by small firms: survey evidence and empirical analysis. Journal of Business Finance \& Accounting,29(3-4), 317-351

Zhou, W. (2009). Bank financing in China's private sector: The payoffs of political capital. World Development,37(4), 787-799. 